\title{
KISARAN INANG DAN DINAMIKA POPULASI Bemisia tabaci (Gennadius) (Hemiptera: Aleyrodidae) DI PERTANAMAN CABAI MERAH
}

\author{
Hendrival $^{1}$, Purnama Hidayat ${ }^{2} \&$ Ali Nurmansyah ${ }^{2}$ \\ ${ }^{1}$ Program Studi Agroekoteknologi, Fakultas Pertanian, Universitas Malikussaleh, \\ Jalan Banda Aceh-Medan, Kampus UNIMAL Cot Tengku Nie, Reuleut, Telp. (0645) 57320, Aceh Utara. \\ E-mail: hendrival@yahoo.com. \\ 2 Departemen Proteksi Tanaman, Fakultas Pertanian, Institut Pertanian Bogor, \\ Jalan Kamper Kampus IPB Darmaga, Bogor 16680, Telp./Fax (0251) 8621267. \\ E-mail: purnamahidayat@gmail.com.
}

\begin{abstract}
Hosts range and dynamic population of Bemisia tabaci (Gennadius) (Hemiptera: Aleyrodidae) in red pepper fields. The study of host range and population dynamic of B. tabaci in red chili pepper fiel dswas conducted in Sub-district of Pakem, District of Sleman, Province of Daerah Istimewa Yogyakarta during dry season of May-October 2009. The study of host plants of $\mathrm{B}$. tabaci from the red chili pepper fields revealed that there were 27 species of host plants belong to 22 genera of 13 families including crops and weeds. The host plants belong to families of Araceae, Amaranthaceae, Asteraceae, Brassicaceae, Capparidaceae, Convolvulaceae, Euphorbiaceae, Lamiaceae, Oxalidaceae, Papilionaceae, Rubiaceae, Solanaceae and Sterculiaceae. The host plant families of Asteraceae and Euphorbiaceae had the most abundant population of $B$. tabaci. Geminivirus-like symptoms were found in the weeds of $A$. conyzoides and A. boehmerioides. Population of $B$. tabaci adults correlated with abundance of host plant species found in the red chili pepper fields. The population of $B$. tabaci in red chili pepper fields was affected by natural enemy population. Population dynamic of the parasitoid Eretmocerus sp. correlated with population dynamic of the parasitized nymph of B. tabaci. Parasitoid Eretmocerus sp. was potentially good in controlling population of $B$. tabaci nymph in red chili pepper fields.
\end{abstract}

Key words: Bemisia tabaci, dynamics population, Eretmocerus sp., host plants

\begin{abstract}
ABSTRAK
Kisaran inang dan dinamika populasi Bemisia tabaci (Gennadius) (Hemiptera: Aleyrodidae) di pertanaman cabai merah. Penelitian tentang kisaran inang dan dinamika populasi B. tabaci di pertanaman cabai merah telah dilakukan di Kecamatan Pakem, Kabupaten Sleman, Provinsi Daerah Istimewa Yogyakarta, selama musim kemarau Mei sampai dengan Oktober 2009. Hasil penelitian terhadap kisaran inang B. tabaci yang tumbuh di area pertanaman cabai merah menunjukkan bahwa terdapat 27 spesies tanaman inang yang terdiri dari 22 genus dari 13 famili yang meliputi tanaman budidaya dan gulma. Spesies inang B. tabaci meliputi Araceae, Amaranthaceae, Asteraceae, Brassicaceae, Capparidaceae, Convolvulaceae, Euphorbiaceae, Lamiaceae, Oxalidaceae, Papilionaceae, Rubiaceae, Solanaceae and Sterculiaceae. Spesies tanaman inang dari family Asteraceae dan Euphorbiaceae merupakan inang dengan kelimpahan populasi B. tabaci paling tinggi. Selain pada tanaman cabai merah, gejala penyakit virus Gemini yang ditularkan oleh B. tabaci juga ditemukan pada gulma Ageratum conyzoides dan Acalypha boehmerioides. Populasi imago B. tabaci dipengaruhi oleh keberadaan spesies tanaman inang B. tabaci yang terdapat di sekitar pertanaman cabai merah dan keberadaan musuh alami. Peningkatan populasi Eretmocerus sp. diikuti dengan peningkatan jumlah nimfa B. tabaci yang terparasit, sehingga dapat menyebabkan penurunan populasi B. tabaci. Parasitoid Eretmocerus sp. Memiliki potensi untuk mengendalikan nimfa $B$. tabaci di pertanaman cabai merah.
\end{abstract}

Kata kunci: Bemisia tabaci, dinamika populasi, Eretmocerus sp., kisaran inang

\section{PENDAHULUAN}

Bemisia tabaci tergolong serangga polifag (Oliveira et al., 2001) dan tersebar luas di daerah subtropis dan tropis (Delatte et al., 2005). B. tabaci diketahui menyerang lebih dari 600 spesies tumbuhan (Oliveira et al., 2001) dan menyebabkan pembentukan bintik-bintik klorotik pada daun dan penutupan stomata oleh embun madu (Byrne \& Bellow, 1991) dan sebagai serangga vektor virus tanaman dari genus Geminivirus 
(Geminiviridae), Crinivirus (Closteroviridae) dan Carlavirus atau Ipomovirus (Potyviridae) (Jones, 2003). Geminivirus merupakan kelompok virus yang paling banyak ditularkan oleh B. tabaci (Brown \& Bird, 1992). Serangan geminivirus pada tanaman cabai di Indonesia dilaporkan terjadi di Provinsi Jawa Barat sejak tahun 1999 (Hidayat et al., 2006). Kejadian penyakit yang disebabkan oleh geminivirus selalu dijumpai sehingga menyebabkan kehilangan hasil yang tinggi terutama pada tanaman cabai (Hidayat \& Rahmayani, 2007). Kehilangan hasil akibat geminivirus dapat mencapai 20-100\% (Sulandari et al., 2006). Tingginya serangan geminivirus berkaitan dengan tingginya populasi B. tabaci seperti dilaporkan oleh Rusli et al. (1999) dan Aidawati et al. (2002), terutama pada musim kemarau yang panjang (Hidayat \& Rahmayani, 2007).

Spesies-spesies inang $B$. tabaci berasal dari famili Asteraceae, Malvaceae, Solanaceae, Cruciferaceae, Lamiaceae, Euphorbiaceae, Fabaceae, Begnoniaceae, Lythraceae dan Zygophyllaceae (Oliveira et al., 2001; Perring, 2001). Jumlah spesies inang paling banyak dijumpai pada famili Fabaceae, sedangkan Begnoniaceae, Lythraceae dan Zygophyllaceae hanya memiliki satu spesies (Oliveira et al., 2001). Inang $B$. tabaci di sekitar pertanaman cabai merah meliputi tanaman budidaya dan gulma. Gulma dapat berperan sebagai inang alternatif geminivirus (Roye \& McLaughlin, 1997; Sukamto, 2005; Sulandari et al., 2006), tempat berlindung bagi imago parasitoid, menyediakan inang alternatif atau sumber makanan seperti nektar, dan polen bagi predator dan parasitoid (Norris \& Kogan, 2005).

Tanaman cabai bukan merupakan inang yang sesuai untuk kolonisasi B. tabaci (Shivanathan, 1983), sehingga populasi B. tabaci jarang ditemukan. Namun kejadian penyakit lebih dominan dijumpai daripada kerusakan akibat aktivitas makan seperti klorotik di pertanaman cabai merah. B. tabaci tergolong sebagai serangga polifag, sehingga sering ditemukan pada tanaman budidaya lainnya dan gulma yang tumbuh di sekitar pertanaman cabai merah. Tanaman budidaya lainnya dan gulma berperan sangat penting dalam perkembangan populasi $B$. tabaci di pertanaman cabai merah. Perubahan perkembangan populasi B. tabaci ditentukan oleh keragaman spesies-spesies inang, penyebaran dari gulma atau tanaman budidaya lainnya yang menjadi inang, dan musuh alami seperti predator dan parasitoid (Henneberry \& Castle, 2001). Penelitian ini bertujuan untuk mengetahui kisaran inang dan dinamika populasi B. tabaci di pertanaman cabai merah.

\section{METODE PENELITIAN}

Penelitian dilaksanakan di Desa Harjobinangun, Kecamatan Pakem, Kabupaten Sleman, Daerah Istimewa Yogyakarta selama musim kemarau Mei sampai Oktober 2009. Lokasi penelitian berada di ketinggian 343 mdpl dan terletak pada $07^{\circ} 40.814 \mathrm{LS}$ dan $110^{\circ} 242.51 \mathrm{BT}$. Identifikasi serangga parasitoid dilakukan di Laboratorium Taksonomi Serangga, Institut Pertanian Bogor, Bogor. Penelitian dilaksanakan pada dua lahan masing-masing seluas $34 \mathrm{~m} \mathrm{x} 12 \mathrm{~m}$, kedua lahan terletak secara terpisah dengan jarak $100 \mathrm{~m}$. Setiap lahan terdiri dari dua petak dengan panjang $16 \mathrm{~m}$ dan lebar $10 \mathrm{~m}$, sehingga terdapat empat petak sebagai ulangan. Setiap petak terdiri dari lima bedengan dengan ukuran panjang $15 \mathrm{~m}$, lebar $1 \mathrm{~m}$, dan tinggi $0,4 \mathrm{~m}$ serta jarak antar bedengan $0,5 \mathrm{~m}$. Varietas cabai merah yang digunakan adalah TM 999 merupakan varietas yang umum ditanam oleh petani setempat. Bibit ditanam dengan jarak tanam $50 \mathrm{~cm}$ (dalam barisan) dan $60 \mathrm{~cm}$ (antarbaris) sehingga terdapat 60 tanaman setiap bedengan. Budidaya tanaman cabai merah mengikuti kebiasaan petani setempat, kecuali aplikasi insektisida dan penyiangan gulma tidak dilakukan selama pertumbuhan tanaman.

Kisaran Inang B. tabaci. Pengambilan sampel dilakukan terhadap tanaman budidaya lainnya atau gulma yang tumbuh di sekitar pertanaman cabai merah. Ukuran sampel bervariasi dari 30-250 daun tergantung pada morfologi dan kepadatan sampel inang. Daundaun sampel disimpan di dalam kantung plastik sebelum dilakukan pengamatan nimfa di bawah mikroskop stereo. Kepadatan sampel inang dikelompokkan dalam kepadatan tinggi, sedang dan rendah. Kepadatan tinggi, jika tanaman atau gulma yang menjadi inang $B$. tabaci dalam jumlah yang banyak terdapat pada semua area yang diamati. Kepadatan sedang, jika tanaman atau gulma yang menjadi inang $B$. tabaci dijumpai dalam jumlah yang sedikit pada semua lokasi dari area yang diamati atau dalam jumlah besar pada beberapa tempat. Kepadatan rendah, jika tanaman atau gulma yang menjadi inang $B$. tabaci dijumpai dalam jumlah sangat sedikit di beberapa tempat (Attique et al., 2003). Analisis vegetasi gulma dilakukan untuk mengetahui susunan vegetasi gulma dan Nisbah Jumlah Dominan (NJD) gulma dengan metode kuadrat (Tjitrosoedirdjo et al., 1984). Analisis vegetasi gulma dilakukan dengan menggunakan petak kuadrat dengan ukuran $0,5 \mathrm{~m}$ x 0,5 $m$ yang diletakkan secara sistematis pada setiap 
bedengan. Identifikasi spesies gulma dilakukan menurut Soerjani et al. (1987), Galinato et al. (1999) dan Martin $\&$ Chanthy (2009).

Dinamika Populasi B. tabaci. Teknik yang digunakan untuk mengamati dinamika populasi $B$. tabaci adalah dengan pengambilan sampel stadia nimfa dan stadia imago. Penghitungan populasi nimfa $B$. tabaci dilakukan dengan cara mengambil tanaman contoh dari seluruh populasi tanaman cabai merah pada petak percobaan. Pola pengambilan tanaman sampel dilakukan secara sistematik, tanaman sampel ditentukan mengikuti baris tanaman dengan jarak delapan tanaman. Jumlah seluruh tanaman sampel dalam satu petak adalah 40 tanaman yang terbagi merata pada kelima bedengan sehingga pada setiap bedengan diambil delapan tanaman sampel, setiap bedengan terdapat 60 tanaman. Metode pengambilan sampel daun dilakukan secara acak untuk mengamati nimfa $B$. tabaci dari setiap tanaman sampel dengan mengambil daun dari bagian atas, tengah dan bawah dari tanaman (Horowitz, 1986). Pada tanaman sampel diambil enam daun (dua bagian atas, dua bagian tengah dan dua bagian bawah). Daun-daun sampel disimpan di dalam kantung plastik untuk dilakukan pemeriksaan terhadap nimfa $B$. tabaci dengan menggunakan mikroskop stereo. Daun-daun yang terdapat nimfa $B$. tabaci dimasukkan secara terpisah ke dalam cawan Petri dan nimfa-nimfa tersebut dipelihara sampai menjadi stadia imago, kemudian dicatat jenis parasitoid yang muncul dan jumlah nimfa $B$. tabaci yang terparasit. Parasitoid yang muncul dikoleksi untuk diidentifikasi berdasarkan Evans \& Serra (2002) dan Evans (2009). Penghitungan populasi imago B. tabaci dilakukan dengan menggunakan kartu kuning berperekat. Kartu kuning berperekat dengan ukuran $(21,5 \mathrm{~cm}$ x 15 $\mathrm{cm}$ ) dipasang pada ketinggian $20 \mathrm{~cm}$ di atas permukaan tanaman yang ditempatkan secara diagonal di dalam petak pertanaman cabai merah. Imago B. tabaci yang terperangkap pada kartu kuning berperekat dihitung jumlahnya di bawah mikroskop stereo. Pengamatan populasi nimfa dan imago B. tabaci dilakukan setiap minggu, mulai tanaman cabai merah berumur 1-16 MST.

Analisis Data. Hubungan populasi parasitoid dengan populasi nimfa $B$. tabaci yang terparasit ditentukan dengan menggunakan analisis regresi. Untuk mengukur kekuatan hubungan antara kedua peubah tersebut ditentukan dengan analisis korelasi. Perbandingan koefisien kemiringan garis regresi dan korelasi dihitung dengan uji t pada taraf nyata $5 \%$. Pengujian parameter regresi ditentukan dengan uji $\mathrm{F}$ pada taraf nyata $5 \%$.
Perhitungan regresi dan korelasi menggunakan program Minitab release 14 (Minitab Statistical Software, 2003).

\section{HASIL DAN PEMBAHASAN}

Kisaran Tanaman Inang B. tabaci. Hasil inventarisasi terhadap gulma yang tumbuh di pertanaman cabai merah terdiri dari 48 spesies meliputi 18 famili dan 42 genus dari tiga tipe gulma yaitu gulma berdaun lebar, berdaun sempit dan teki. Gulma berdaun lebar lebih banyak tumbuh dibandingkan gulma berdaun sempit dan teki. Spesies gulma yang dominan dijumpai adalah Ageratum conyzoides $(\mathrm{NJD}=10,4 \%)$, Portulaca oleraceae $(10,1 \%)$, Synedrella nodiflora $(\mathrm{NJD}=6,1 \%)$ dan Cleome viscosa $(5,7 \%)$ dari tipe gulma berdaun lebar, Cyperus compressus $(\mathrm{NJD}=5,5 \%)$ dan Cyperus rontundus $(\mathrm{NJD}=4,7 \%)$ dari tipe gulma teki, dan Eleusine indica $(\mathrm{NJD}=4,9 \%)$ dan Brachiaria distachya $(\mathrm{NJD}=2,2 \%)$ dari tipe gulma berdaun sempit. Gulma A. conyzoides dan P. oleraceae merupakan spesies yang paling banyak tumbuh serta memiliki pertumbuhan dan penyebaran lebih cepat dibandingkan spesies lainnya. Tanaman budidaya lainnya yang tumbuh di sekitar pertanaman cabai merah terdiri dari tujuh spesies meliputi enam famili dan tujuh genus. Tanaman budidaya lainnya adalah kacang tanah (Arachis hypogaea), ubi kayu (Manihot esculenta), ubi jalar (Ipomoea batatas), jagung (Zea mays), talas (Colocasia esculenta), terung (Solanum melongena), pisang (Musa paradisiaca) dan padi (Oryza sativa). Tanaman padi, kacang tanah, ubi kayu, ubi jalar, jagung, dan talas tumbuh sebelum tanaman cabai merah di tanam. Tanaman terung tumbuh setelah tanaman cabai merah ditanam. Tanaman budidaya tersebut merupakan tanaman yang sering dibudidayakan petani di Desa Harjobinangun, Kecamatan Pakem, Kabupaten Sleman, DIY sepanjang musim tanam.

Spesies inang B. tabaci yang tumbuh di sekitar pertanaman cabai merah meliputi 27 spesies dari 13 famili, dengan klasifikasi tujuh famili memiliki satu spesies inang yaitu Araceae, Brassicaceae, Convolvulaceae, Oxalidaceae, Papilionaceae, Rubiaceae dan Sterculiaceae. Empat famili memiliki dua spesies inang yaitu Amaranthaceae, Capparidaceae, Lamiaceae dan Solanaceae. Famili Asteraceae memiliki lima spesies inang dan Euphorbiaceae memiliki spesies paling banyak yaitu tujuh spesies inang. Spesies-spesies inang B. tabaci tersebut meliputi tanaman budidaya lainnya dan gulma. Spesies gulma yang menjadi inang $B$. tabaci adalah gulma berdaun lebar dari tipe gulma anual, sedangkan gulma dari golongan daun sempit dan teki 
diketahui bukan sebagai inang B. tabaci. Spesies gulma yang paling banyak tersebar serta memiliki pertumbuhan dan perkembangan sejak awal pertumbuhan sampai tanaman cabai merah dipanen adalah $A$. conyzoides, $S$. nodiflora, C. viscosa, C. rutidosperma, P. niruri, $P$. debilis dan Physalis angulata. Spesies-spesies tersebut dijumpai dalam jumlah yang banyak pada semua petak pengamatan sehingga dikelompokkan dalam spesies inang yang memiliki kepadatan tinggi. Gejala penyakit seperti terinfeksi virus tanaman dijumpai pada gulma A. conyzoides dan A. boehmerioides. Gejala penyakit pada kedua gulma berupa penguningan lamina dan tulang daun yang menyerupai jala. Tanaman budidaya lainnya yang tumbuh di sekitar pertanaman cabai yang diketahui sebagai inang $B$. tabaci adalah ubi kayu, ubi jalar, kacang tanah, terung dan talas (Tabel $1)$.

Jumlah spesies-spesies inang B. tabaci pada pertanaman cabai merah masih lebih rendah dibandingkan dengan jumlah spesies inang di pertanaman kapas seperti dilaporkan oleh Attique et al. (2003) yang menemukan 160 spesies inang terdiri dari 113 genus dan 42 famili. Kisaran inang B. tabaci yang tumbuh di sekitar pertanaman kapas meliputi tanaman pangan, hias, buah-buahan dan gulma. Tanaman budidaya lainnya yang tumbuh di sekitar pertanaman cabai merah yang menjadi inang B. tabaci adalah $M$. esculenta, $I$. batatas, A. hypogaea, S. melongena dan C. esculenta. Beberapa tanaman budidaya tersebut juga merupakan inang $B$. tabaci yang tumbuh di sekitar pertanaman kapas seperti dilaporkan oleh Attique et al. (2003) yaitu C. esculenta, I. batatas dan S. melongena. Hasil penelitian Alegbejo \& Banwo (2005) juga menunjukkan bahwa tanaman budidaya seperti M. esculenta, A. hypogaea, I. batatas dan S. melongena merupakan inang dari B. tabaci yang terdapat di Samaru, Nigeria. Hasil yang sama juga dilaporkan oleh McKenzie et al. (2004) yang menyatakan bahwa A. hypogaea dan $S$. melongena merupakan inang B. tabaci di Florida.

Peranan karakteristik spesies inang seperti morfologi merupakan sumber rangsangan utama dalam proses pemilihan dan penentuan inang oleh $B$. tabaci (Henneberry \& Castle 2001). Hasil pengamatan menunjukkan bahwa karakteristik morfologi merupakan sumber rangsangan utama pemilihan dan penentuan inang oleh B. tabaci seperti trikoma pada daun. $B$. tabaci memiliki preferensi yang tinggi terhadap spesies inang yang memiliki trikoma pada permukaan bawah daun seperti $A$. conyzoides, S. nodiflora dan $S$. melongena. B. tabaci kurang menyukai spesies inang yang tidak memiliki trikoma pada daun seperti $H$. brevipes, L. lavandulaefolia, O. barrelieri,
A. viridis dan $R$. brasiliensis. Seperti dikemukakan oleh Indrayani \& Sulistyowati (2005) bahwa B. tabaci mempunyai preferensi tinggi terhadap tanaman inang yang daunnya memiliki trikoma, dan kurang menyukai yang tidak memiliki trikoma.

Hasil pengumpulan nimfa $B$. tabaci dari setiap spesies inang yang dijumpai selama pertumbuhan tanaman cabai merah menunjukkan bahwa terdapat satu jenis parasitoid dari golongan Hymenoptera dan famili Aphelinidae yaitu Eretmocerus sp. Terdapat 20 spesies inang dari jenis gulma dan tanaman budidaya lainnya yang berperan menyediakan inang alternatif bagi imago parasitoid Eretmocerus sp. di pertanaman cabai merah. Tingkat parasitisasi parasitoid Eretmocerus sp. pada nimfa $B$. tabaci dari spesies inang tersebut berkisar antara 3,4\% sampai 30,7\% (Tabel 1). Spesies-spesies gulma yang tumbuh di pertanaman cabai merah lebih banyak berperan sebagai tempat berlindung dan menyediakan inang alternatif bagi imago parasitoid Eretmocerus sp. Griffiths et al. (2008) menyatakan bahwa ketersediaan tempat berlindung bagi musuh alami di ekosistem pertanian dapat meningkatkan efektivitas musuh alami dalam pengendalian hayati hama tanaman. Selanjutnya Emden (1991) menyatakan bahwa gulma dapat menjadi inang alternatif bagi parasitoid, pada saat inang utama pada tanaman budidaya menurun akibat aplikasi insektisida. Gulma dapat menyediakan makanan tambahan bagi imago parasitoid seperti tepung sari dan nektar.

Dinamika Populasi B. tabaci. Populasi imago B. tabaci mulai dijumpai di pertanaman cabai merah sejak 1 MST dengan rata-rata kerapatan 18,78 imago per kartu kuning berperekat. Sampai pada 5 MST, populasi imago masih relatif tinggi dan peningkatan populasi imago maksimum terjadi pada 6 MST dengan rata-rata kerapatan 23,39 imago per kartu kuning berperekat (Gambar 1A). Peningkatan populasi imago B. tabaci yang terjadi pada 1 MST sampai 6 MST karena jumlah spesies-spesies inang yang banyak muncul pada 1 MST sampai 6 MST. Jumlah spesies inang paling banyak dijumpai pada $1 \mathrm{MST}$ sebesar 5,75 spesies per minggu (Gambar 1D). Spesies inang tersebut meliputi M. esculenta, C. esculenta, I. batatas, Arachis hypogaea, Ageratum conyzoides, Cleome viscosa, Phyllanthus debilis, P. niruri dan Physalis angulata. Penurunan populasi imago $B$. tabaci yang terjadi setelah 6 MST sampai 12 MST karena jumlah spesies-spesies inang juga mengalami penurunan pada waktu yang sama serta beberapa spesies inang sudah mencapai pertumbuhan generatif sehingga berkurang sumber makanan bagi B. tabaci seperti A. viridis, A. spinosus, 
Tabel 1. Kepadatan spesies inang B. tabaci, populasi nimfa B. tabaci, dan tingkat parasitisasi parasitoid Eretmocerus sp. pada spesies inang yang tumbuh di lahan pertanaman cabai merah pada musim kemarau Juni sampai Oktober tahun 2009 di Desa Harjobinangun, Kecamatan Pakem, Kabupaten Sleman, DIY

\begin{tabular}{|c|c|c|c|c|}
\hline Famili & Spesies & $\begin{array}{c}\text { Kepadatan } \\
\text { spesies inang }\end{array}$ & $\begin{array}{l}\text { Rata-rata nimfa } \\
\text { B. tabaci per daun }\end{array}$ & $\begin{array}{l}\operatorname{Parasitisasi}^{\mathrm{a}}(\%) \\
(\mathrm{r})^{\mathrm{b}}(\mathrm{n})^{\mathrm{c}}\end{array}$ \\
\hline Amaranthaceae & Amaranthus spinosus $^{\mathrm{d}}$ & Sedang & 0,24 & $16,7 \quad(2) \quad(12)$ \\
\hline Amaranthaceae & A. viridis $^{\mathrm{d}}$ & Sedang & 0,41 & $9,7 \quad$ (4) (41) \\
\hline Araceae & Colocasia esculenta $^{\mathrm{e}}$ & Rendah & 0,70 & $\begin{array}{lll}0 & (0) & (21)\end{array}$ \\
\hline Asteraceae & Ageratum conyzoides $^{\mathrm{d}}$ & Tinggi & 0,89 & $11,2(25)(223)$ \\
\hline Asteraceae & Crassocephalum crepidiodes ${ }^{\mathrm{d}}$ & Rendah & 0,46 & $\begin{array}{lll}0 & (0) & (14)\end{array}$ \\
\hline Asteraceae & Eclipta prostrata & Sedang & 0,57 & $15,8 \quad(9) \quad(57)$ \\
\hline Asteraceae & Erigeron sumatrensis ${ }^{\mathrm{d}}$ & Rendah & 0,40 & $\begin{array}{lll}0 & (0) & (24)\end{array}$ \\
\hline Asteraceae & Synedrella nodiflora ${ }^{\mathrm{d}}$ & Tinggi & 0,44 & $3,4 \quad$ (3) (88) \\
\hline Brassicaceae & Rorippa indica ${ }^{\mathrm{d}}$ & Sedang & 0,92 & $14,1(13) \quad(92)$ \\
\hline Capparidaceae & Cleome rutidosperma ${ }^{\mathrm{d}}$ & Tinggi & 0,48 & $8,3 \quad(6) \quad(72)$ \\
\hline Capparidaceae & C. viscosa $a^{\mathrm{d}}$ & Tinggi & 0,63 & $13,7(13) \quad(95)$ \\
\hline Convolvulaceae & Ipomoea batatas $^{\mathrm{e}}$ & Sedang & 0,74 & $5,4 \quad(3) \quad(74)$ \\
\hline Euphorbiaceae & Acalypha boehmerioides ${ }^{\mathrm{d}}$ & Sedang & 0,23 & $4,3 \quad$ (1) (23) \\
\hline Euphorbiaceae & Euphorbia hirta ${ }^{\mathrm{d}}$ & Sedang & 0,32 & $10,2 \quad(5) \quad(49)$ \\
\hline Euphorbiaceae & E. hypericifolia ${ }^{\mathrm{d}}$ & Sedang & 0,26 & 30,7 (4) (13) \\
\hline Euphorbiaceae & E. prunifolia ${ }^{\mathrm{d}}$ & Sedang & 1,60 & $8,7(21)(240)$ \\
\hline Euphorbiaceae & Phyllanthus debilis ${ }^{\mathrm{d}}$ & Tinggi & 0,27 & $17,5 \quad(7) \quad(40)$ \\
\hline Euphorbiaceae & P. niruri $^{\mathrm{d}}$ & Tinggi & 0,61 & $14,3(13) \quad(91)$ \\
\hline Euphorbiaceae & Manihot esculenta ${ }^{\mathrm{e}}$ & Sedang & 8,17 & $0 \quad(0)(485)$ \\
\hline Lamiaceae & Hyptis brevipes $^{\mathrm{d}}$ & Sedang & 0,32 & $18,7 \quad(6) \quad(32)$ \\
\hline Lamiaceae & Leucas lavandulaefolia ${ }^{\mathrm{d}}$ & Rendah & 0,32 & $\begin{array}{lll}0 & (0) & (16)\end{array}$ \\
\hline Oxalidaceae & Oxalis barrelieri $^{\mathrm{d}}$ & Rendah & 0,40 & $0 \quad(0) \quad(20)$ \\
\hline Papilionaceae & Arachis hypogaea ${ }^{\mathrm{e}}$ & Tinggi & 0,51 & $4,9 \quad(5)(102)$ \\
\hline Rubiaceae & Richardia brasiliensis $^{\mathrm{d}}$ & Rendah & 0,30 & $25,0 \quad$ (3) (12) \\
\hline Solanaceae & Physalis angulata ${ }^{\mathrm{d}}$ & Tinggi & 1,01 & $8,6(22)(254)$ \\
\hline Solanaceae & Solanum melongena ${ }^{\mathrm{e}}$ & Tinggi & 3,80 & $12,6(24)(190)$ \\
\hline Sterculiaceae & Melochia concatenata $^{\mathrm{d}}$ & Sedang & 0,36 & $\begin{array}{lll}0 & (0) \quad(36)\end{array}$ \\
\hline
\end{tabular}

A. conyzoides, S. nodiflora, R. indica, $C$. viscosa, C. rutidosperma, $M$. concatenata dan $P$. angulata atau tanaman budidaya lainnya yang sudah dipanen seperti kacang tanah dan ubi jalar. Populasi imago B. tabaci mengalami kenaikan kembali sejak 13 MST sampai 16 MST. Kenaikan populasi imago B. tabaci terjadi karena pada 13 MST mulai dijumpai spesies inang baru yang tumbuh di pertanaman cabai merah seperti C. crepidodes, $H$. brevipes, E. prostrata,
E. sumatrensis dan L. lavandulaefolia. Spesiesspesies inang berperan sangat penting dalam perkembangan populasi imago $B$. tabaci.

Spesies inang B. tabaci seperti M. esculenta, C. esculenta, I. batatas dan A. hypogaea yang tumbuh sebelum tanaman cabai merah ditanam dapat membangun populasi imago $B$. tabaci sebelum tanaman cabai merah ditanam. Sesuai pernyataan Attique et al. (2003), spesies inang B. tabaci di pertanaman kapas 
berperan dalam membangun populasi $B$. tabaci sebelum tanaman kapas ditanam dan dapat mendatangkan B. tabaci ke pertanaman kapas. Tersedianya spesies inang, baik tanaman budidaya maupun gulma sepanjang pertumbuhan tanaman cabai merah akan berpengaruh terhadap perkembangan populasi $B$. tabaci. Seperti menurut Henneberry \& Castle (2001) dan Leite et al. (2005), perubahan populasi B. tabaci salah satunya dipengaruhi oleh ketersediaan spesies inang lainnya yang tumbuh di sekitar pertanaman.

Pengamatan terhadap populasi nimfa $B$. tabaci menunjukkan bahwa populasi nimfa mulai dijumpai di pertanaman cabai merah sejak 1 MST dengan rata-rata kerapatan 0,11 nimfa per daun, namun belum dijumpai nimfa yang terparasit. Peningkatan populasi nimfa terjadi pada $4 \mathrm{MST}$, peningkatan populasi nimfa juga diikuti dengan peningkatan jumlah nimfa yang mati karena terparasit oleh parasitoid Eretmocerus sp., sehingga populasi nimfa mengalami penurunan pada 5 MST (Gambar 1B). Populasi nimfa mengalami peningkatan yang tajam serta mencapai populasi maksimum pada 8 MST dengan kerapatan 2,96 nimfa per daun dan menurun pada 9 MST (1,77 nimfa per daun). Peningkatan populasi nimfa $B$. tabaci pada 8 MST diikuti dengan peningkatan jumlah nimfa yang terparasit sehingga terjadi peningkatan populasi imago Eretmocerus sp. (Gambar 1C). Populasi nimfa B. tabaci mengalami kenaikan kembali pada $10 \mathrm{MST}$ dengan kerapatan 2,43 nimfa per daun, namun masih rendah dibandingkan dengan populasi pada 8 MST. Sedangkan jumlah nimfa $B$. tabaci terparasit lebih banyak dijumpai pada 10 MST dibandingkan dengan 8 MST, sehingga populasi imago Eretmocerus sp. mengalami peningkatan yang lebih tinggi (1,28 imago per daun) dibandingkan pada 8 MST. Populasi nimfa B. tabaci mengalami penurunan kembali setelah 10 MST sampai 16 MST, namun populasi nimfa tersebut masih lebih tinggi dibandingkan dengan populasi nimfa pada awal pengamatan (1 MST) (Gambar 1B).

Berdasarkan hasil analisis ragam menunjukkan bahwa parameter regresi berbeda nyata berdasarkan uji $\mathrm{F}(\mathrm{F}=1796,15 ; \mathrm{db}=14 ; \mathrm{P}<0,05)$ yang mengindikasikan bahwa populasi parasitoid Eretmocerus sp. dapat mempengaruhi populasi nimfa $B$. tabaci yang terparasit di pertanaman cabai merah yang dinyatakan dengan persamaan $\mathrm{w}=-0,115+0,963 \mathrm{x}$ dan koefisien determinasi dari parameter regresi adalah $\mathbf{R}^{2}=0,992$. Koefisien kemiringan garis regresi berbeda nyata berdasarkan uji $\mathrm{t}(\mathrm{t}=2,145 ; \mathrm{b}=0,963 \pm 0,227 ; \mathrm{P}<0,05)$ yang juga mengindikasikan bahwa populasi parasitoid Eretmocerus sp. dapat mempengaruhi dinamika populasi nimfa
B. tabaci. Koefisien korelasi $(\mathrm{r}=0,996 ; \mathrm{P}<0,05)$ menunjukkan bahwa terdapat hubungan positif antara populasi parasitoid Eretmocerus sp. dengan populasi nimfa $B$. tabaci yang terparasit. Peningkatan populasi parasitoid Eretmocerus sp. dapat menyebabkan peningkatan populasi nimfa $B$. tabaci yang terparasit. Peningkatan populasi Eretmocerus sp. diikuti dengan peningkatan jumlah nimfa yang mati karena terparasit oleh parasitoid Eretmocerus sp., sehingga dapat menyebabkan penurunan populasi imago $B$. tabaci di pertanaman cabai merah.

Parasitoid Eretmocerus sp. mulai memarasit nimfa B. tabaci instar ke-2 sampai ke-4 (Gerling et al., 2001), namun preferensinya lebih tinggi pada nimfa instar ke-2. Nimfa-nimfa B. tabaci yang terparasit oleh parasitoid Eretmocerus sp. mengalami kematian pada instar ke-4. Parasitoid Eretmocerus sp. dapat menyelesaikan siklus hidupnya sampai fase imago pada satu nimfa B. tabaci atau bersifat soliter. Seperti dikemukakan Driesche \& Bellows (1996) dan Hajek (2004), parasitoid yang perkembangan hidupnya terjadi pada satu tubuh inang disebut parasitoid soliter dan bersifat endoparasitoid. Selanjutnya Zolnerowich \& Rose (2008) menyatakan bahwa parasitoid Eretmocerus sp. merupakan parasitoid soliter dan endoparasitoid yang memarasit nimfa $B$. tabaci instar kedua dan imago parasitoid muncul dari nimfa instar ke-4 yang telah mati.

Parasitoid Eretmocerus sp. merupakan parasitoid nimfa dari $B$. tabaci yang paling dominan ditemukan pada pertanaman cabai merah di Provinsi Jawa Barat, Jawa Tengah dan DIY seperti dilaporkan oleh Hidayat et al. (2009). Parasitoid Eretmocerus sp. memiliki potensi dalam pengendalian hayati $B$. tabaci di pertanaman cabai merah. Seperti yang dikemukakan oleh Castineiras (1995), Gerling et al. (2001), dan Kirk et al. (2001), genus Eretmocerus merupakan parasitoid $B$. tabaci yang telah banyak digunakan untuk pengendalian hayati $B$. tabaci. Pengendalian hayati B. tabaci merupakan salah satu komponen pengendalian hama terpadu memiliki peranan dalam mencegah berkembangnya populasi $B$. tabaci yang telah resistensi terhadap insektisida. Pengendalian hama secara hayati merupakan implementasi kestabilan komunitas. Kestabilan komunitas merupakan implikasi tingginya keanekaragaman spesies penyusun komunitas tersebut. Komunitas akan menjadi stabil bila terdapat berbagai spesies musuh alami dalam komunitas tersebut. Musuh alami berperan penting dalam mengatur populasi hama B. tabaci (Naranjo, 2001). 

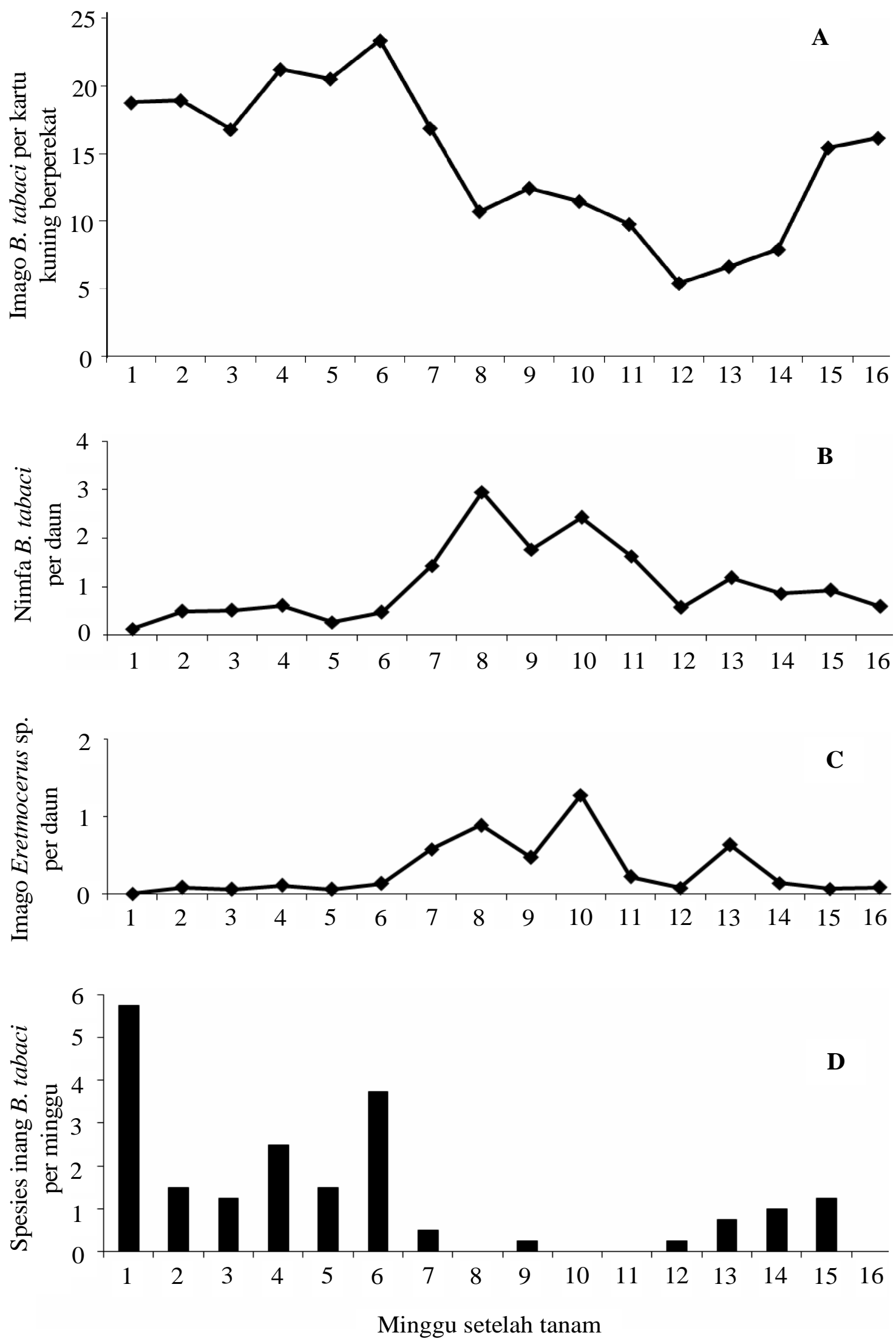

Gambar 1. Perkembangan populasi imago dan nimfa B. tabaci (A dan B), populasi imago parasitoid Eretmocerus sp. (C) dan spesies inang $B$. tabaci (D) di pertanaman cabai merah pada setiap minggu setelah tanam 


\section{SIMPULAN}

Kisaran inang B. tabaci yang tumbuh di sekitar pertanaman cabai merah terdiri dari 27 spesies dari 22 genus dan 13 famili meliputi tanaman budidaya lainnya dan gulma. Spesies inang tersebut berasal dari famili yaitu Amaranthaceae, Araceae, Asteraceae, Brassicaceae, Capparidaceae, Convolvulaceae, Euphorbiaceae, Lamiaceae, Oxalidaceae, Rubiaceae, Papilionaceae, Solanaceae, dan Sterculiaceae. Famili Asteraceae dan Euphorbiaceae merupakan inang dengan populasi $B$. tabaci paling banyak dibandingkan dengan famili lainnya. Perkembangan populasi imago $B$. tabaci berasosiasi dengan keberadaan spesies inang $B$. tabaci yang terdapat di sekitar pertanaman cabai merah. Dinamika populasi nimfa $B$. tabaci dipengaruhi oleh parasitoid Eretmocerus sp. Peningkatan populasi Eretmocerus sp. diikuti dengan peningkatan jumlah nimfa yang mati karena terparasit sehingga dapat menyebabkan penurunan populasi imago $B$. tabaci.

\section{SANWACANA}

Penelitian ini terlaksana berkat dukungan dana dari Project ACIAR-AVRDC Chili IDM tahun 2009 melalui Dr. Ir. Sri Hendrastuti Hidayat, M.Sc, Institut Pertanian Bogor, Bogor. Ucapan terima kasih disampaikan kepada Ir. Bagus Kukuh Udiarto, M.P., Pak Ngadimin dan Pak Mardi yang telah membantu pelaksanaan penelitian.

\section{DAFTAR PUSTAKA}

Aidawati N, Hidayat SH, Suseno R \& Sosromarsono S. 2002. Transmission of an Indonesian isolate of tobacco leaf curl virus (Geminivirus) by Bemisia tabaci Genn. (Hemiptera: Aleyrodidae). Plant Pathol. 18: 231-236.

Alegbejo MD \& Banwo OO. 2005. Host plants of Bemisia tabaci Genn. in Northern Nigeria. $J$. Plant Protect Res. 45(2): 93-98.

Attique MR, Rafiq M, Ghaffar A, Ahmad Z \& Mohyuddin AI. 2003. Hosts of Bemisia tabaci (Genn.) (Homoptera: Aleyrodidae) in cotton areas of Punjab, Pakistan. Crop Protection 22: 715720.

Brown JK \& Bird J. 1992. Whitefly-transmitted geminivirus and associated disorders in the
Americas and the Caribbean Basin. Plant Disease 76: 220-225.

Byrne DN \& Bellows Jr TS. 1991. Whitefly biology. Ann. Rev. Entomol. 36: 431-457.

Castineiras A. 1995. Natural enemies of Bemisia tabaci (Homoptera: Aleyrodidae) in Cuba. Florida Entomologist 78(3): 538-540.

Delatte H, Reynaud B, Granier M, Thornary L, Lett JM, Goldbach R \& Peterschmitt M. 2005. A new silverleaf-inducing biotype $\mathrm{M}$ of Bemisia tabaci (Hemiptera: Aleyrodidae) indigenous to the islands of the south-west Indian Ocean. Bull. Entomol. Res. 95: 29-35.

Driesche RGV \& Bellows Jr TS. 1996. Biological Control. Chapman \& Hall, London.

Emden HF van. 1991. Plant diversity and natural enemy efficiency in agroecosystems. Pp. 63-80 In: Mackauer M, Ehler LE \& Roland J, eds. Critical Issu in Biological Control. Cambridge University Press, London.

Evans GA \& Serra CA. 2002. Parasitoids associated with whiteflies (Homoptera: Aleyrodidae) in Hispaniola and descriptions of two new species of Encarsia (Hymenoptera: Aphelinidae). J. Hym. Res. 11(2): 197-212.

Evans GA. 2009. Key to parasitoid genera associated with whiteflies (Aleyrodidae). http:// www.sel.barc.usda.gov:8080/1WF/couplet1.html. Diakses tanggal 14 Desember 2009.

Galinato MI, Moody K \& Piggin CM. 1999. Upland Rice Weeds of South and Southeast Asia. International Rice Research Institute, Los Banos Philippines.

Gerling D, Alomar O \& Arno J. 2001. Biological Control of Bemisia tabaci using Predators and Parasitoids. Crop Protection 20: 779-799.

Griffiths GJK, Holland JM, Bailey A \& Thomas MB. 2008. Efficacy and economics of shelter habitats for conservation biological control. Biological Control 45: 200-209. 
Hajek AN. 2004. Natural Enemies: An Introduction to Biological Control. Cambridge University Press, London.

Henneberry TJ \& Castle SJ. 2001. Bemisia: pest status, economics, biology, and population dynamics. Pp: 247-278 In: Harris KF, Smith OP \& Duffus JE, eds. Virus-Insect-Plant Interactions. Academic Press, London.

Hidayat SH, Chatchawankanpanich O, Rusli E \& Aidawati N. 2006. Begomovirus associated with pepper yellow leaf curl disease in West Java, Indonesia. J. Indon. Microbiol. 11(2):87-89.

Hidayat SH \& Rahmayani E. 2007. Transmission of Tomato leaf curl begomovirus by two different species of whitefly (Hemiptera: Aleyrodidae). $J$. Plant Pathol. 23(2): 57-61.

Hidayat P, Setiawati W \& Murtiningsih RRR. 2009. Strategi pemanfaatan musuh alami dalam pengendalian Bemisia tabaci (Gennadius) (Hemiptera: Aleyrodidae) sebagai vektor virus kuning pada pertanaman cabai merah. Laporan Penelitian KKP3T. Institut Pertanian Bogor, Bogor.

Horowitz AR. 1986. Population dynamics of Bemisia tabaci (Gennadius): with special emphasis on cotton fields. Agric. Ecosyst. Environ. 17: 3747.

Indrayani IGAA \& Sulistyowati E. 2005. Pengaruh kerapatan bulu daun pada tanaman kapas terhadap kolonisasi Bemisia tabaci Gennadius. Jurnal Penelitian Tanaman Industri 11(3): 101106.

Jones D. 2003. Plant viruses transmitted by whiteflies. Eur. J. Plant Pathol. 109: 197-221.

Kirk AA, Lacey LA \& Goolsby JA. 2001. Classical biological control of Bemisia and successful integration of management strategies in the United States. Pp: 309-329 In: Harris KF, Smith OP \& Duffus JE, eds. Virus-Insect-Plant Interactions. Academic Press, London.
Leite GLD, Picanço M, Jham GN \& Moreira MD. 2005. Whitefly population dynamics in okra plantations. Pesq. Agropec. Bras. 40(1): 19-25.

Martin R \& Chanthy P. 2009. Weeds of Upland Crops in Cambodia. Australian Centre for International Agricultural Research, Australia.

McKenzie CL, Anderson PK \& Villarreal N. 2004. An extensive survey of Bemisia tabaci (Homoptera: Aleyrodidae) in agricultural ecosystems in Florida. Florida Entomologist 87(3): 403-407.

Minitab Statistical Software. 2003. Meet Minitab Release 14 For Windows. Minitab Inc. Pennsylvania.

Naranjo SE. 2001. Conservation and evaluation of natural enemies in IPM systems for Bemisia tabaci. Crop Protection 20: 835-852.

Norris RF \& Kogan M. 2005. Ecology of interaction between weeds and arthtropods. Ann. Rev. Entomol. 50: 479-503.

Oliveira MRV, Henneberry TJ \& Anderson P. 2001. History, current status, and collaborative research projects for Bemisia tabaci. Crop Protection 20: 709-723.

Perring TM. 2001. The Bemisia tabaci species complex. Crop Protection 20: 725-737.

Roye ME \& McLaughlin WA. 1997. Genetic diversity among geminivirus associated with the weed species Sida spp., Macropilium lathyroides, and Wissadula amplissima from Jamaica. Plant Disease 81(11): 1251-1258.

Rusli ES, Hidayat SH, Suseno R \& Tjahjono B. 1999. Virus gemini pada cabai: variasi gejala dan studi cara penularan. Buletin Hama dan Penyakit Tumbuhan 11(1): 26-31.

Shivanathan P. 1983. The epidemiology of three diseases caused by whitefly-borne pathogens. Pp. 323330 In: Plumb RT \& Thresh JM, eds. Plant Virus Epidemiology. Oxford University Press, United Kingdom. 
Soerjani M, Kostermans AJGH \& Tjitrosoepomo G, editor. 1987. Weeds of Rice in Indonesia. Balai Pustaka, Jakarta.

Sulandari S, Suseno R, Hidayat SH, Hardjosudarmo J \& Sosromarsono S. 2006. Deteksi dan kajian kisaran inang penyebab penyakit daun keriting kuning cabai. Hayati 13(1): 1-6.

Sukamto. 2005. Begomovirus associated with leaf curl disease of tomato in Java, Indonesia. Phytophatology 153: 562-566.
Tjitrosoedirdjo S, Utomo IH \& Wiroatmodjo. 1984. Pengendalian Gulma di Perkebunan. PT. Gramedia Pustaka Utama, Jakarta.

Zolnerowich G \& Rose M. 2008. The genus Eretmocerus. Pp. 89-109 In: Gould J, Hoelmer K \& Goolsby J, eds. Classical Biological Control of Bemisia tabaci in the United StatesA Review of Interagency Research and Implementation. Springer, Netherlands. 